\title{
ANALISIS DAN PERANCANGAN SISTEM INFORMASI PADA BRASTAGI SUPERMARKET RANTAUPRAPAT DENGAN MENERAPKAN VIEWPOINT ORIENTED REQUIREMENT DEFINITION (VORD) BERBASIS WEB
}

\author{
Dyah Faramida Octaviani Lubis ${ }^{1}$, Posma Lumbanraja ${ }^{2}$, Jhoni Maslan Hutapea ${ }^{3}$ \\ ${ }^{1,2,3}$ Program Studi Sistem Informasi Fakultas Ilmu Komputer \\ Universitas Methodist Indonesia \\ 1'dyahfaramida7@gmail.com
}

\begin{abstract}
Brastagi Supermarket Rantauprapat is a branch of Brastagi Supermarket Medan which is located on Jl. Gatot Subroto. In its management, Brastagi Supermarket Rantauprapat is different from Brastagi Supermarket in other cities, because Brastagi Supermarket Rantauprapat is a separate management unit from other branches. The ongoing business process at Brastagi Supermarket is that buyers must come directly to the supermarket location to purchase products from the supermarket. Brastagi Supermarket Rantauprapat already uses a computerized system in carrying out its business processes, but the system used is still limited to the cashier system, where when the buyer has finished shopping, they will make a transaction at the cashier. The current system has a weakness where people still have to come directly to the location to make purchase transactions. Considering that there are no e-commerce transactions at Brastagi Rantauprapat and the many other competitors as well as the current pandemic effect, it is imperative that online transactions be carried out and the products ordered are delivered to the place. This information system applies the Viewpoint Oriented Requirements Definition (VORD) method. The Viewpoint Oriented Reqruiment Definition (VORD) method is a method for analyzing system requirements using the Viewpoint approach. The advantage of the VORD method itself is that the VORD method can address the needs of various user perspectives, thus creating a framework to differentiate user needs. The implementation of this filing system uses PHP and MySQL programming.
\end{abstract}

Keywords- Needs Analysis, Brastagi Supermarket, Information System, Vord

\section{PENDAHULUAN}

Brastagi Supermarket Rantauprapat adalah Supermarket Bintang Lima yang ada di kota Rantauprapat. Brastagi Supermarket Rantauprapat merupakan cabang dari Brastagi Supermarket Medan yang berada di J1.Gatot Subroto. Brastagi Supermarket memiliki cabang di beberapa lokasi, seperti di Medan Cambridge City Square Medan, Rantauprapat, Tiara Convention Centre Medan, dan Manhattan Times Square Medan. Maka dengan itu Brastagi Supermarket Rantauprapat adalah cabang ke 3. Dalam pengelolaannya Brastagi Supermarket Rantauprapat berbeda dengan Brastagi Supermarket di kota lainnya, karena Brastagi Supermarket Rantauprapat merupakan bagian manajemen yang terpisah dari cabang lainnya. Proses bisnis yang sedang berjalan di Brastagi Supermarket adalah pembeli harus datang langsung ke lokasi supermarket untuk melakukan pembelian produk yang ada pada supermarket. Brastagi Supermarket Rantauprapat sudah menggunakan sistem yang terkomputerisasi dalam menjalankan proses bisnisnya namun sistem yang digunakan masih hanya sebatas untuk sistem kasir, dimana saat pembeli sudah selesai berbelanja akan melakukan transaksi pembayaran di kasir. Sistem yang ada saat ini memiliki kelemahan dimana masyarakat masih harus datang langsung ke lokasi untuk melakukan transaksi pembelian.

Ditengah Pandemi Covid-19 yang semakin merebak terjadi pembatasan kegiatan di luar rumah, keadaan ini memengaruhi aktivitas individu dalam melakukan pembelian. Kebiasaan berbelanja dimasyarakat mengalami banyak perubahan semenjak pandemik virus corona ini masuk ke Indonesia, karena dengan adanya pembatasan untuk melakukan kegiatan di luar rumah, masyakarat memilih untuk berbelanja melalui online. Pada kondisi seperti ini belanja online menjadi pilihan terbaik yang bisa dilakukan oleh masyarakat yang ingin tetap melakukan aktivitas pembelian. Masyarakat dapat dengan mudah membeli suatu barang dengan hanya bermodalkan aplikasi maupun website melalui handphone dan melakukan pembayaran melalui mobile banking. Hal ini dapat menghemat waktu dan tenaga dilihat dari masyarakat tidak perlu datang langsung ke supermarket.

Belanja secara online atau sering disebut dengan $e$ commerce memiliki beberapa keunggulan yang dapat dirasakan bagi penggunanya seperti tidak perlu keluar rumah ataupun pergi ketempat belanja, yang dibutuhkan hanyalah memesan barang tersebut kemudian barang tersebut akan diantarkan kerumah. Keunggulan lainnya yang dapat dirasakan adalah hemat waktu dalam membeli dan dalam hal berbelanja, kita juga dapat mengontrol harga atau membandingkan harga dari beberapa tempat supermarket lainnya.

Berdasarkan hal tersebut dan mengingat belum ada transaksi e-commerce di Brastagi Rantauprapat dan banyaknya kompetitor lain serta adanya pengaruh 
pandemik saat ini, memaksa harus dapat dilakukan transaksi online dan produk yang dipesan di antar ke tempat, melatarbelakangi perlu analisis dan merancang sistem baru yang merupakan pengembangan sistem penjualan lama.

\section{METODE PENELITIAN}

Metode yang digunakan untuk melakukan proses analisa kebutuhan adalah metode Viewpoint Oriented Requirement Definition (VORD). Viewpoint Oriented Requirements Definition (VORD) adalah salah satu metode untuk menganalisis kebutuhan sistem dengan menggunakan pendekatan sudut pandang.

Metode ini dikembangkan oleh Gerald Kotonya dan Ian Sommerville pada tahun 1996. Menurut Gerald Kotonya and Ian Sommerville, hal yang terpenting dalam membuat perangkat lunak adalah pada proses analisa kebutuhan, bukan pada coding atau desain dari perangkat lunak. Sedangkan menurut Zelika, VORD sangat berguna dalam menemukan kebutuhan user dan juga berguna dalam mengidentifikasi sistem. VORD terfokus pada entitas eksternal yang berinteraksi dengan sistem. Oleh karenanya VORD merepresentasikan kebutuhan dari sistem berdasarkan entitas viewpoint.

Metode ini dikembangkan untuk membantu proses spesifikasi dari interaksi sistem. Metode Viewpoint Oriented Requirement Definition (VORD) adalah salah satu metode yang dapat digunakan untuk pendefinisian kebutuhan perangkat lunak. Metode VORD menggambarkan kebutuhan sistem sebagai suatu layanan yang diberikan oleh sistem terhadap viewpoint. Terdapat beberapa jenis viewpoint yaitu :

1. Interactor viewpoint - orang atau sistem lain yang berinteraksi secara langsung dengan sistem (contoh : customer, pegawai dll).

2. Indirect viewpoint - stakeholder yang tidak menggunakan sistem tetapi mempengaruhi jalannya sistem (contoh : karyawan keamanan, cleaning service dll).

3. Domain viewpoint - karakteristik ranah dan batasan yang mempengaruhi kebutuhan sistem.

VORD didasarkan pada empat tahap utama, antara lain:

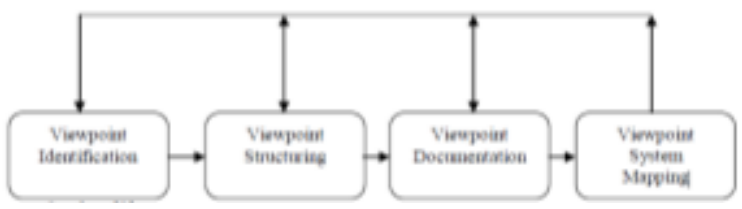

Gambar 1. Tahapan VORD

1. Identifikasi Viewpoint

Menemukan viewpoint sebagai penerima layanan sistem dan mengidentifikasikan layanan yang disediakan untuk masing-masing viewpoint.

Di dalam tahap ini, dilakukan identifikasi terhadap kebutuhan dengan langkah sebagai berikut :

a. Mendaftar semua stakeholder yang ada di dalam sistem perangkat lunak tersebut dengan melakukan brainstorming. b. Mengidentifikasi mana yang termasuk ke dalam viewpoint dan service (layanan) di dalam kebutuhan sistem perangkat lunak.

2. Pembentukan Struktur Viewpoint

Mengelompokkan viewpoint yang saling berhubungan secara hierarki. Layanan umum disediakan pada level yang lebih tinggi dalam hierarki. Tujuan dari viewpoint documentation ini adalah untuk memetakan kebutuhan sistem atau layanan terhadap masing- masing viewpoint sesuai dengan viewpoint Structuring.

3. Dokumentasi Viewpoint

Memperbaiki deskripsi viewpoint dan layanan yang teridentifikasi

4. Viewpoint system Mapping

Transformasi analisis ke perancangan berorientasi objek.

\section{HASIL DAN PEMBAHASAN}

Adapun hasil yang diterapkan adalah antara lain:

\section{Viewpoint Identification}

Identifikasi viewpoint meliputi penentuan viewpoint berdasarkan layanan yang akan diterima oleh setiap viewpoint. Pada tahap ini, dilakukan identifikasi terhadap kebutuhan yang dijelaskan dengan mendaftar semua stakeholder yang terdapat dalam sistem tersebut.

Tujuan analisa kebutuhan ini adalah untuk membagi ruang lingkup sistem berdasarkan kebutuhan fungsional untuk masing-masing pengguna dan kebutuhan nonfungsional yang berkaitan dengan kebutuhan fungsional tersebut.

Viewpoint yang terdapat didalam sistem:

1. Admin Brastagi Supermarket

2. Customer Brastagi Supermarket

3. Admin Five star Karaoke

4. Pelanggan Five star Karaoke

5. Admin Cafe Kedai Pojok

6. Kasir Café Kedai Pojok

7. Supplier Brastagi Supermarket

8. Lingkungan Brastagi Supermarket

9. Peraturan Brastagi Supermarket

10. Komputer

11. Akses Internet/ Wifi

12. Kecepatan Akses Internet

13. Ruang Penyimpanan

\section{Viewpoint Structuring}

Pengguna Sistem Informasi Brastagi Supermarket ini memiliki Tujuh (7) aktor yang terdiri dari admin supermarket, customer supermarket, supplier, admin karaoke, dan pelanggan karaoke, admin kedai pojok, kasir kedai pojok. 


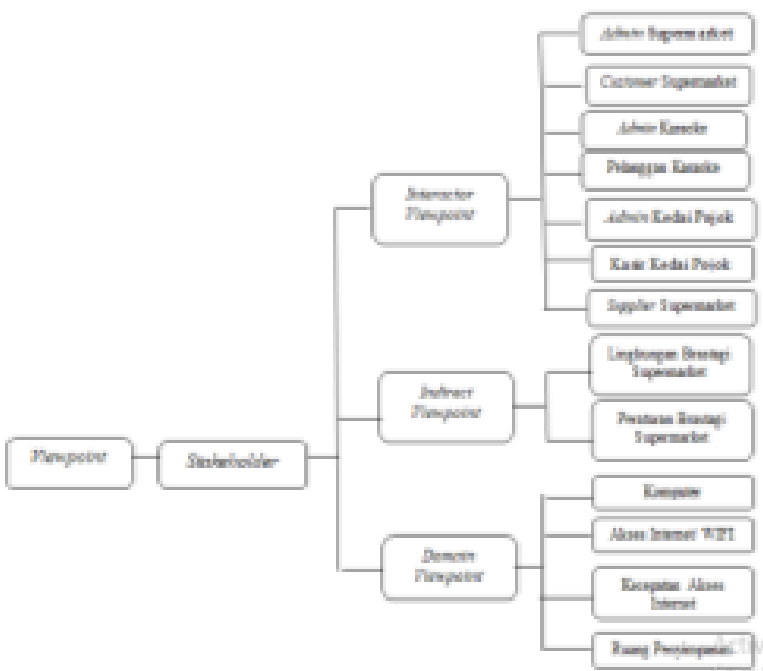

Gambar 2. Viewpoint Structuring melakukan transaksi online.

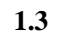

Tersedia fungsi untuk Fun masuk ke dalam sistem (login) dan keluar dari system (logout)

Fungsi login menggunakan parameter username dan password

1.3.1 Tersedia fungsi untuk melihat dan menambah data karyawan, dan data room karaoke

1.3.2 Melihat Data Reservasi Fun

\section{Viewpoint Documentation}

Dokumentasi viewpoint meliputi cara untuk mendeskripsikan setiap viewpoint dan layanan yang telah ditentukan sebelumnya.

Tujuan dari viewpoint documentation ini adalah untuk memetakan kebutuhan sistem atau layanan terhadap masing-masing viewpoint sesuai dengan viewpoint Structuring. Hasil dari viewpoint documentation dapat digunakan sebagai acuan dalam pembuatan use case. Bentuk dari dokumentasi VORD seperti ditunjukkan pada tabel dibawah ini.

Tabel 1. Kebutuhan Interactor Viewpoint

\begin{tabular}{|c|c|c|c|c|}
\hline \multicolumn{3}{|c|}{ Viewpoint } & \multicolumn{2}{|c|}{ Requirement } \\
\hline \multirow{8}{*}{$\begin{array}{l}\text { Identifier } \\
1 .\end{array}$} & Label & & cription & Type \\
\hline & $\begin{array}{l}A d m i \\
n \\
\text { Superm } \\
\text { rket }\end{array}$ & 1.1 & $\begin{array}{l}\text { Tersedia fungsi untuk } \\
\text { masuk ke dalam } \\
\text { sistem (login) dan } \\
\text { keluar dari system } \\
\text { (logout) }\end{array}$ & Fun \\
\hline & & & $\begin{array}{l}\text { Fungsi login } \\
\text { menggunakan } \\
\text { parameter } \text { username } \\
\text { dan password }\end{array}$ & NFun \\
\hline & & 1.1.1 & $\begin{array}{l}\text { Tersedia fungsi untuk } \\
\text { melihat dan menambah } \\
\text { data karyawan, data } \\
\text { customer, data data } \\
\text { supplier }\end{array}$ & Fun \\
\hline & & 1.1.2 & $\begin{array}{l}\text { Tersedia fungsi untuk } \\
\text { melihat transaksi } \\
\text { pembelian dan laporan } \\
\text { history sistem. }\end{array}$ & Fun \\
\hline & $\begin{array}{l}\text { Custom } \\
\text { er } \\
\text { Superm } \\
\text { arket }\end{array}$ & 1.2 & $\begin{array}{l}\text { Tersedia fungsi untuk } \\
\text { masuk ke dalam } \\
\text { sistem (login) dan } \\
\text { keluar dari system } \\
\text { (logout) }\end{array}$ & Fun \\
\hline & & & $\begin{array}{l}\text { Fungsi login } \\
\text { menggunakan } \\
\text { parameter } \text { username } \\
\text { dan password. }\end{array}$ & NFun \\
\hline & & 1.2.1 & $\begin{array}{l}\text { Tersedia fungsi untuk } \\
\text { melakukan pemesanan } \\
\text { terhadap produk yang } \\
\text { ingin dibeli dan dapat }\end{array}$ & Fun \\
\hline
\end{tabular}

Tersedia fungsi untuk memberikan status reservasi karaoke pada data reservasi.

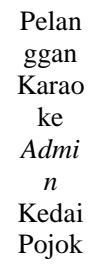

\section{4}

Tersedia Menu pemesanan room karaoke

Tersedia fungsi untuk masuk ke dalam sistem (login) dan keluar dari system (logout)

Fungsi login menggunakan parameter username dan password

1.5.1 Tersedia fungsi untuk melihat data karyawan,data kasir, data menu, dan laporan transaksi.

1.5.2 Tersedia fungsi untuk Fun melihat transaksi penjualan

Kasir

Kedai Pojok

\section{6}

Tersedia fungsi untuk masuk ke dalam sistem (login) dan keluar dari system (logout)

Fungsi login

menggunakan parameter username dan password

1.6.1 Tersedia fungsi untuk melakukan transaksi pemesanan.
Fun NFun

(n)
Fun

Fun

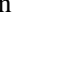




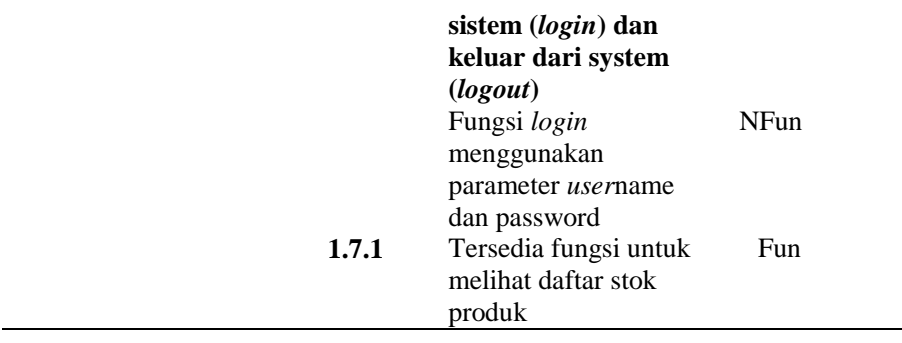

Tabel 2. Kebutuhan Indirect Viewpoint

\begin{tabular}{|c|c|c|c|c|}
\hline \multirow{2}{*}{ Identifier } & \multirow{2}{*}{$\begin{array}{l}\text { Viewpoint } \\
\text { Label }\end{array}$} & \multicolumn{3}{|c|}{ Requirement } \\
\hline & & & escription & Type \\
\hline & $\begin{array}{l}\text { Lingkungan } \\
\text { Brastagi } \\
\text { supermarket }\end{array}$ & 2.1 & $\begin{array}{l}\text { Sistem Informasi } \\
\text { Brastagi } \\
\text { Supermarket dapat } \\
\text { diakses oleh pihak } \\
\text { internal Brastagi } \\
\text { Supermarket, yaitu } \\
\text { admin supermarket, } \\
\text { admin kedai pojok, } \\
\text { kasir kedai pojok, } \\
\text { dan admin karaoke }\end{array}$ & Nfun \\
\hline & & 2.2 & $\begin{array}{l}\text { Sistem dapat } \\
\text { menjalankan fungsi- } \\
\text { fungsi yang } \\
\text { dibutuhkan } \\
\text { pengguna sesuai } \\
\text { dengan hak } \\
\text { aksesnya }\end{array}$ & Nfun \\
\hline 3 & $\begin{array}{l}\text { Peraturan } \\
\text { Brastagi } \\
\text { Supermarket }\end{array}$ & 3.1 & $\begin{array}{l}\text { Sistem informasi } \\
\text { Brastagi } \\
\text { Supermarket yang } \\
\text { dijalankan } \\
\text { sepenuhnya dimiliki } \\
\text { oleh Brastagi } \\
\text { Supermarket } \\
\text { Rantauprapat. }\end{array}$ & Nfun \\
\hline
\end{tabular}

\section{Viewpoint System Mapping}

Berdasarkan analisis interaksi terhadap viewpoints, maka dapat ditentukan layanan sistem yang akan disediakan oleh sistem informasi Brastagi Supermarket. Kemudian dilakukan Transformasi analisis ke perancangan berorientasi objek seperti gambar di bawah.

\section{Halaman Utama Customer}

Pada halaman ini customer dapat melihat produk supermarket, room five star karaoke dan menu yang ada pada kedai pojok. Halaman Utama customer dapat dilihat pada gambar 3 dibawah.

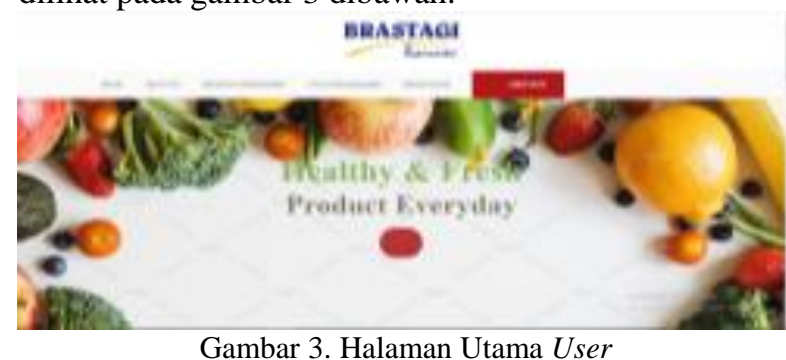

Halaman Produk Supermarket dapat dilihat pada gambar 4. User dapat melihat produk beserta harga dari setiap produk.

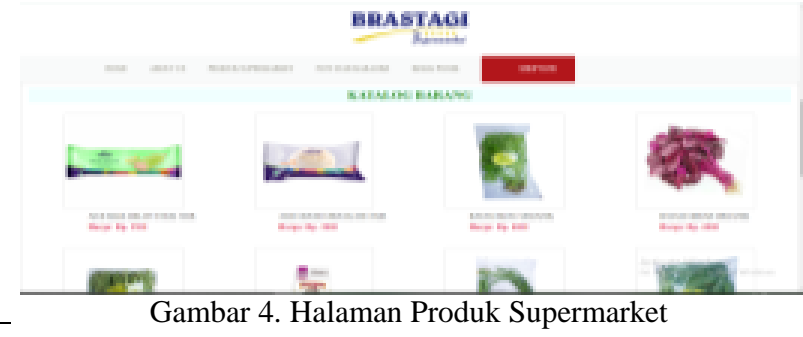

Halaman Five star Karaoke dapat dilihat pada gambar 5. customer dapat melihat type room beserta harga dari setiap room.

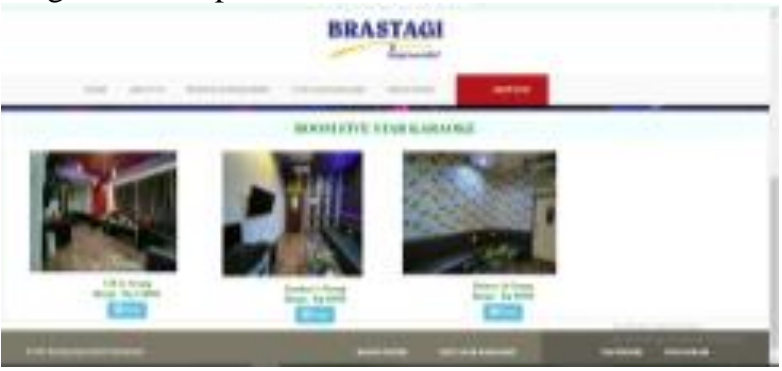

Gambar 5. Halaman Five star Karaoke

Halaman Kedai Pojok dapat dilihat pada gambar 6. customer dapat melihat menu yang tersedia pada kedai pojok yang ada di supermarket brastagi beserta harga dari setiap menu.

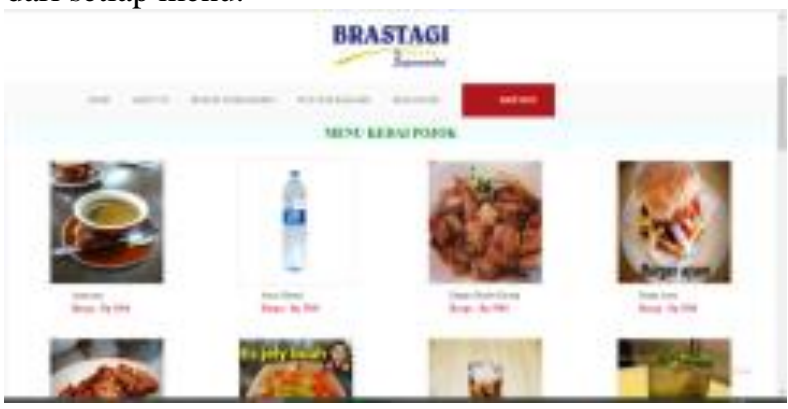

Gambar 6 Halaman Kedai Pojok

2. Halaman Pemesanan Produk Supermarket

Halaman Pemesanan Produk Supermarket dapat dilihat pada gambar 7 dibawah. Customer supermarket dapat memilih produk yang ingin dipesan.

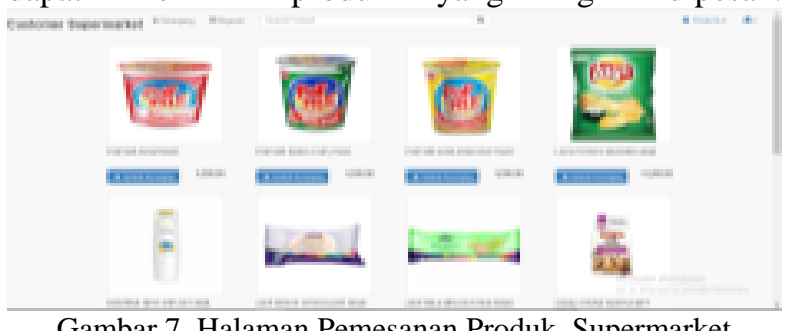

Gambar 7. Halaman Pemesanan Produk Supermarket

3. Halaman Detail Pesanan Customer Supermarket

Pada halaman ini customer dapat melihat detail dari pesanan produk yang telah dilakukan. 


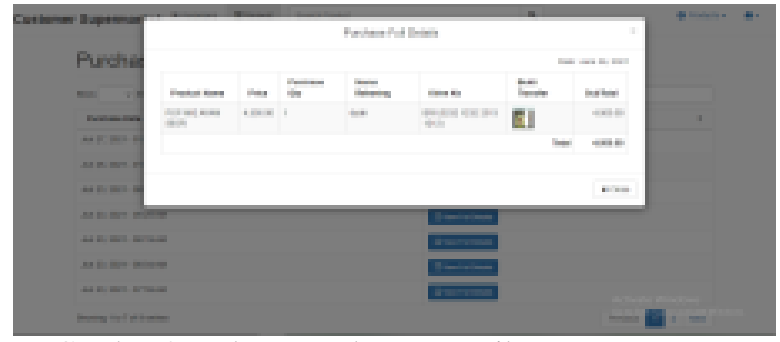

Gambar 8. Halaman Halaman Detail Pesanan Customer Supermarket

4. Halaman Pemesanan Room Karaoke

Pada Halaman ini, user dapat melakukan pemesanan room karaoke. Halaman Pemesanan Room Karaoke dapat dilihat pada gambar 9.

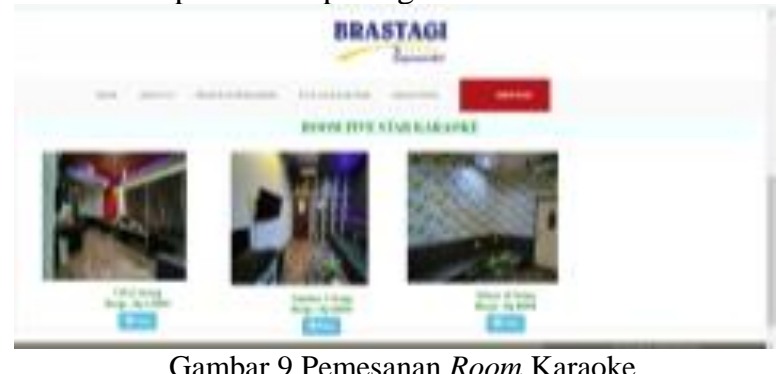

5. Halaman Pengisian Data Pemesanan Room Karaoke

Pada Halaman ini, user dapat melakukan pemesanan room karaoke. User akan mengisi data-data untuk proses reservasi room.

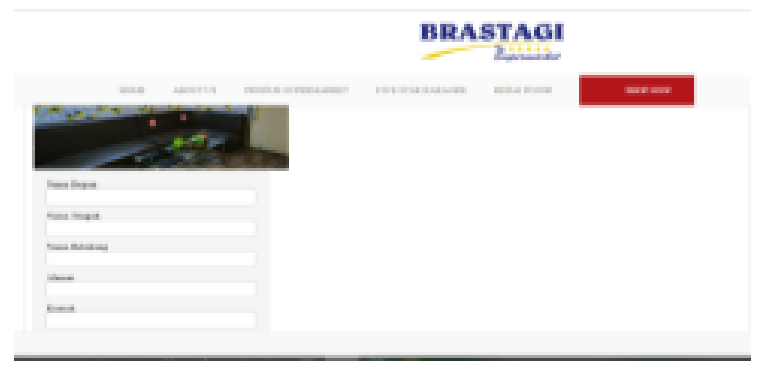

Gambar 10. Halaman Pengisian Data Pemesanan Room Karaoke

6. Halaman Sales Report

Gambar 11. merupakan tampilan halaman Sales Report. Pada halaman ini admin dapat melihat pesanan pelanggan.

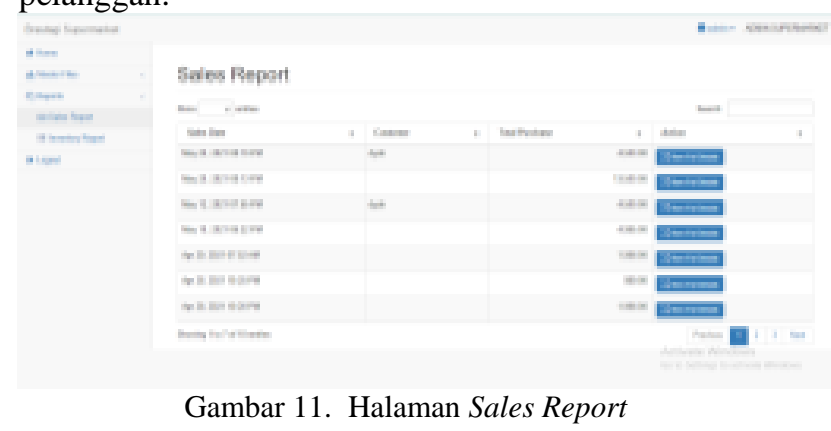

7. Halaman Utama Supplier
Pada halaman ini supplier dapat melihat stok produk yang tersisa pada supermarket.

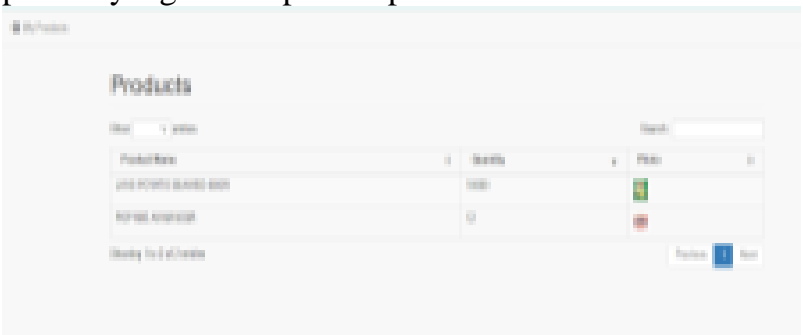

Gambar 12. Halaman Utama Supplier Supermarket

8. Halaman Kasir

Pada Halaman Kasir ini, kasir akan memasukkan data pesanan menu pelanggan yang datang. Halaman kasir dapat dilihat pada gambar 13.

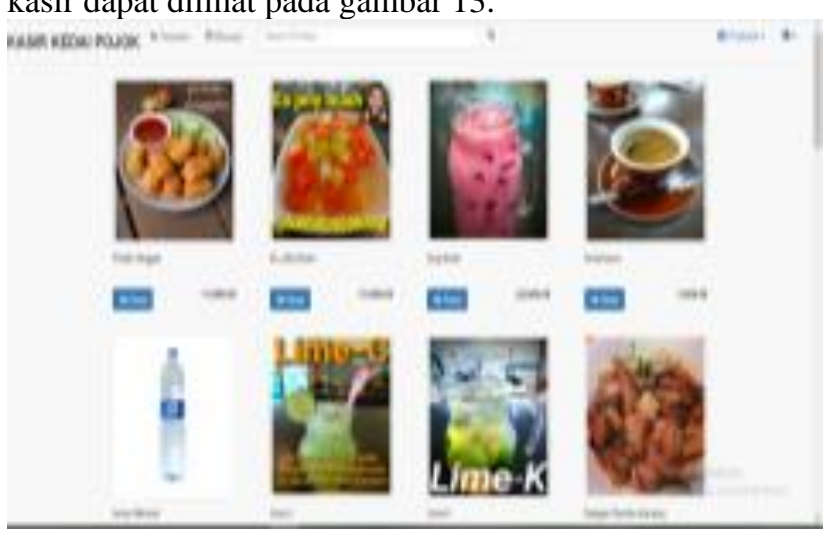

Gambar 13. Halaman Kasir

\section{KESIMPULAN}

Berdasarkan hasil pengujian dari sistem yang telah dibuat maka dapat ditarik sebuah kesimpulan yaitu sebagai berikut :

1. Sistem informasi berbasis website yang diterapkan dengan VORD memudahkan dalam menganalisis perangkat lunak sesuai kebutuhan stakeholder

2 Dengan adanya sistem informasi berbasis web ini dapat membuat Brastagi Supermarket Rantauprapat lebih dikenal dan mempermudah pengunjung dalam memperoleh data produk yang ada di supermarket brastagi maupun room yang tersedia pada five star karaoke.

3. Sistem informasi untuk memberikan kemudahan administrasi dalam penyimpanan dan pengolahan data yang guna mempermudah kinerja dalam operasional.

\section{REFERENSI}

[1]. A. Holil and N. Ali, "Analisis Kebutuhan Untuk Pengembangan Sistem Informasi Produksi Di Pt . Z Dengan Metode Vord ( Viewpoints Oriented Requirements Definition )," Pros. Semin. Nas. Manaj. Teknol. XIV, 2011.

[2]. Alvisha Farrasita Istifani and Sholiq, "Rancang Bangun Aplikasi Koperasi Simpan Pinjam dengan Metode Viewpoint Oriented Requirement Definition," J. Sisfo, vol. 07, no. 02, 2018.

[3]. C. Tambunan, D. R. Manalu, and J. F. Naibaho, "Penerapan Customer Relationship Management Pada Sistem Informasi Pemesanan Dan Penjualan Pada Toko Buku Gapura Berbasis Web," J. Method., vol. 4, no. 1, pp. 27-31, 2018. 
[4]. D. S. Informasi, "Pinjam Dengan Metode Viewpoint Oriented Requirement Definition . (Studi Kasus : Koperasi Karyawan Pt Wonosari Jaya)," 2018.

[5]. D. Wahyuningsih, "Sistem Penggajian Karyawan Tirtonirmolo3 dengan Metode Viewpoints Oriented Reqruiments Definition (VORD)," Konf. Nas. Sist. Inf., pp. 8-9, 2018.

[6]. I. Br Sembiring, D. Robinson Manalu, S. Sitepu, J. Maslan Hutapea, and A. Gea, "Perancangan Aplikasi Marketplace Pemesanan Jasa Tukang Kunci Berbasis Android," METHOSISFO J. Ilm. Sist. Inf., vol. 1, no. 1, pp. 1-6, 2021.

[7]. I. K. J. Melani Feruche, DR Manalu, "Sistem Informasi Marketplace Penyewan Properti," vol. 8, pp. 92-99, 2018.

[8]. Mulyani, Sri. 2016. Analisis dan Perancangan Sistem Informasi. Jakarta:

AbdiSistematika

[9]. Wibawa M. B, 2016, Performance Assessment System Needs Analysis Of Lp3i Business College Lecturer Banda Aceh Using The Method Of Viewpoint Oriented Requirement Definition (Vord), Vol 2, No 2 (2016): Oktober 2016 